\title{
Bacteriophages: A Potential Next Generation Biocontrol Tool for Plant Disease Management
}

\author{
P. Barua* and P.D. Nath \\ Department of Plant Pathology, Faculty of Agriculture, Assam Agricultural University, \\ Jorhat-785013, Assam, India \\ *Corresponding author
}

\section{A B S T R A C T}

\begin{tabular}{|l|}
\hline K e y w o r d s \\
Bacteriophage, Phage \\
biology, Phage based \\
biocontrol
\end{tabular}

\section{Introduction}

Bacteriophages or the phages are the viruses that parasitize bacteria. The introduction of bacteriophages to the world began one hundred and three years ago in 1915 when F. W. Twort reported that he observed some 'glassy transformation' on cultures of micrococci. However after two years, in 1917, Felix d' Herelle, a Canadian bacteriologists working at the Pasteur Institute in Paris, also published his independent discovery of bacteriophages (Summers, 2006). The term bacteriophages was given by Felix d'Herelle from 'bacteria' and the Greek word 'phagein' which means 'to eat' referring to the

\begin{abstract}
The biocontrol potential of the bacteriophages has been known to man since its discovery a century ago. Bacteriophage therapy or the use of bacteriophages for the management of bacterial diseases is a concept with a controversial past and hence, still an uncommon practice especially in the agricultural sector. However, in the present decade there has been a renewed interest and several successful researches owing to the better understanding of sequencing and metagenomics. Moreover, the bacteriophages are a potential solution to mitigate the existing challenges like the emergence and re-emergence of pathogenic bacteria, development of multi drug resistant bacteria, environmental hazards due to over use of chemicals etc. This article gives an overview on the bacteriophages and their potential to utilize them in the field of agriculture with an aim to build up the interest of further research on it, especially in India to handle the bacterial diseases organically.
\end{abstract}

remarkable ability of the bacteriophages to cause lysis of growing bacterial cultures (Ceyssens, 2009).

Since its discovery in the early $20^{\text {th }}$ century, the bacteriophages were widely used as therapeutic agents against human and animal bacterial diseases. Experiments regarding the use of phages as biocontrol agents in agriculture soon followed similar trend. However, in spite of the popular and promising success of the early phage therapy, it did not prove to be reliable and effective means for the control of bacterial diseases. The widespread success and availability of broad spectrum antibiotics, inconsistent results 
on the efficiency of phage therapy probably due to lack of knowledge regarding the bacteriophages and credibility problems caused by lack of quality control and properly controlled studies led to the decline of phage therapy trials both in the field of medicine and agriculture (Jones et al., 2007). Gill and Hyman, (2010) listed out three major factors that led to the failure of early phage therapy: inappropriate phage choice, poor phage preparation and phage decay prior to application.

The most frequent management tactic for the control of bacterial diseases is the use of antibiotics. However, the major problem of most antibiotics is that they are broad spectrum in their mode of action. The indiscriminant targeting of bacteria by broad spectrum antibiotics causes generation of resistance to a wide range of bacterial population. Moreover, overuse of antibiotics has led to the spread of R-plasmids and multidrug resistant (MDR) strains. This has led to re- evaluation and re- thinking of the use of phages as biological control agents (BCA) (Wu et al., 2013). In the present decade however, better understanding of the phages, phage-host interactions, better isolation, characterization, propagation as well as delivery has become possible with the help of modern biotechnological tools. This has led to a great spike in phage therapy research all over the world. USA, Japan, China and European countries play a lead role in the phage therapy research as well as field level application. In India however, it is still an uncommon practice. The present article gives an overview of the bacteriophages and the recent trends in their application in the field of agriculture.

\section{Phage biology and classification}

Bacteriophages are the most abundant organisms on Earth. It has been estimated that there are approximately $10^{30}$ bacterial cells in the biosphere and about $10^{31}$ phages in the planet. This makes the viral to bacterial ratio to be around 5-10: 1 (Hatfull, 2008). Phages are natural parasites of the bacteria and are found ubiquitously in nature. It is believed that at least a single type of phage, more likely more than one can infect every strain of bacteria (Keen, 2015). As calculated by viral ecologists, globally there are about $10^{23}$ phage infections per indicating the dynamic nature of the phage population apart from its huge numbers (Hatfull and Hendrix, 2012)

Bacteriophages are polyphyletic in origin as they are extremely heterogeneous in their structural, physiochemical and biological properties (Ackermann, 2005). They show a great diversity in their morphology as well as genomics.

\section{Phage morphology}

Like all viruses, a bacteriophage particle or virion is composed of a single or double stranded (ss or ds) DNA or RNA which is encapsulated inside a protein or a lipoprotein coat. The morphology of the bacteriophage plays a major role in their classification. The main foundation for the present phage classification was given by Bradley in 1967. Bradley reported six different morphological types of phages, exemplified by phages $\mathrm{T} 4, \lambda$, T7, $\Phi \times 174$, MS2 and fd. The International Committee on the Taxonomy of Viruses (ICTV) uses virion morphology and nucleic acid composition as a basis for the classification. The latest report (10th) ICTV has been published in the year 2017 (https://talk.ictvonline.org/ictv-

reports/ictv_online_report).

There are a total of 19 morphotypes of bacteriophages according to ICTV, amongst which the best studied and a vast majority (96\%) belongs to the order Caudovirales 
having an icosahedral or elongated head and a tail (Latin Cauda means tail). They are known to infect both Eubacteria and Archaea and are probably as ancient as 3.5 billion years old (Ackermann, 2005; Ackermann, 2009b). The tailed phages are monophyletic in origin possessing related morphologic, physiochemical and physiological properties. The most distinguishing characteristics are that they contain dsDNA, have icosahedral or elongated heads, the tails are elongated and possess some fixation structures like base plates, spikes and fibers and they do not have envelope (Ackermann, 2009b).

The order Caudovirales is divided into 3 families which are as follows (Ackermann, 2009b):

\section{Myoviridae}

The tail of myoviruses is composed of a neck, a contractile sheath and a central tube. They are larger in size than other groups and are highly evolved. Around $25 \%$ of the tailed phages belong to this family.

\section{Siphoviridae}

The tails are simple, non- contractile, flexible or rigid tubes. They are the most numerous of the tailed phages. It comprises of around $61 \%$ of the tailed phages.

\section{Podoviridae}

The tails of podoviruses are short and noncontractile. They are more related to Siphoviridae than Myoviridae. Podoviruses comprises of approximately $14.5 \%$ of the tailed phages.

Use of electron microscopy is one of the major tools for the characterization of bacteriophages, mainly the unknown phages as it is based on visualization and morphological identification of the viral particles. Ruska in 1940 (cited by Ackermann, 2009a) published the first electron micrographs of bacteriophages in which the lysis caused by coliphages to an E. coli cells were photographed. The discovery of the negative staining technique by Brenner and Horne in 1959 can be regarded as a landmark as it greatly boosted its use for virus detection. As reported by Ackermann and Prangishvili (2012), around 6300 prokaryote viruses have been described morphologically since the discovery of negative staining in 1959, amongst which 6196 were bacterial and 88 archaeal viruses.

\section{Phage genomics}

According to Ackermann (2009b), the phage genomes include double-stranded DNA (dsDNA), single- stranded DNA (ssDNA), single- stranded RNA (ssRNA), and doublestranded RNA (dsRNA). The vast majority of the phages contain dsDNA whereas; phages containing dsRNA are very rare. All the DNA phages contain a single molecule of DNA and several phages have lipid containing envelops or internal vesicles (Ackermann, 2005). The phage diversity is also reflected in their genome sizes. The phage genome size are reported to range from 2,435bp in Leuconostoc phage L5 (Hatful, 2008) to 497,513bp in Bacillus megaterium phage G (Donelli et.al., 1975). Hatful, 2008 reports that the distribution of genome sizes of the phages are not uniform. The largest peak of which is seen at 30-50kbp interval (approximately 50\% of all phages) followed by the group whose genomes are smaller than 10kbp (about 20\% of total) and those in 100- 200kbp interval (6\% of total). The tailed phages having more than 200bp are classified as jumbo phages. Yuan and Gao (2017) suggested that the jumbo phages possesses several novel characters not seen in other phages with smaller genomes. These jumbo phages have 
evolved from the phages with smaller genomes by acquiring some additional functional genes which in turn reduces its dependence on host bacteria.

Due to their relatively small genome sizes and simplicity of isolation, the complete genomes of the bacteriophages can be sequenced quite easily. Some major events in history regarding the sequencing of phage genomes are depicted in Table 1.

\section{Phage life-cycles and their impact in phage based biocontrol}

The bacteriophages can be considered as parasites of bacteria as they rely on their host bacteria for the completion of their life cycle. They can undergo two different types of life cycles: the lytic and the lysogenic cycle. The phages gets adsorbed to the host bacterium at some specific receptor sites like protein receptors (structural proteins interacting with peptidoglycan layer, specific and non-specific porins forming membrane channels, enzymes, substrate receptors with high affinity, transport proteins responsible for secretions), or lipopolysaccharide (LPS) receptors in case of gram negative bacteria etc. (Rakhuba et al., 2010). In lytic cycle, after the adsorption of the phage particle on the host bacterium, only the nucleic acid of the phage particle is penetrated inside the host cell. This results in switching off the protein mechanism of the host bacterium in the favor of the phages resulting in production phage proteins and nucleic acid. Hence, a large number of progeny phages are formed weakening the host, thus resulting in lysis and death of the host cell. The bacteriophages which show the lytic cycle are also widely known as virulent phages. Some examples of virulent phages are Coliphage T4, Coliphage T2 etc. (Adams, 1959; Orlova, 2012). As mentioned by Orlova (2012), as many as 50-200 new phages can be released from a single phage particle after completion of the lytic cycle. The word 'lysogeny' on the other hand means 'generating lysis' (Lwoff, 1953). A lysogenic infection or life cycle can be characterized by incorporation of the phage DNA into the genome of the host bacterium and thus replication of the phage DNA along with the replication of the host (Orlova, 2012). A lysogenic bacterium can undergo many cell divisions without losing its lysogenic property. Lysis of a lysogenic bacterium spontaneously or in response to certain environmental factors is accompanied by the release of many mature phage particles. However, if a lysogenic bacterium is disrupted, no infectious particles are known to be released (Lwoff, 1953; Adams, 1959; Brathwaite, 2015). The prokaryote which harbors latent phages is known as lysogenic and the latent form of the phage is known as prophage (Adams, 1959; Campbell, 2006). The bacteriophages that show a latent state are known as temperate or lysogenic phages such as Coliphage $\lambda, \mathrm{Mu}-1$ etc.).

Selection of the right kind of phage is the key for successful phage based biocontrol mechanisms. Only the virulent phages are capable of causing lysis of their host bacterial cells and hence are of prime interest in phage therapy. The lytic phages have a narrow host range i.e. they are known to infect only specific bacterial species (Doss et al., 2017). Some phages are known to infect only a few strains of one species of bacteria, while some others may be species specific as well as genus specific (Gill and Hyman, 2010). This is a boon as the phages are target specific and does not infect the other beneficial bacteria of the biosphere. However, due to their high specificity, it is more likely that a phage cocktail is required against a particular bacterial disease to counter all the strains of the bacterial pathogen. To use the phages for bio- control purpose, it is desirable to perform the host range analysis and choose the phages 
that allow productive infection on all strains of the pathogen genus or species being targeted (Buttimer et al., 2017). Apart from that, some lytic phages are also capable of transduction i.e. bacterial gene transfer with the aid of phages (Klumpp et al., 2008). For successful phage based bio-control, the lysogenic and transducing phages should be eliminated during selection.

\section{Application of phages in plant disease management}

Although a vast majority of plant diseases are of fungal origin, the bacterial plant pathogens are highly devastating and are responsible to cause major economic losses every year. Management of the plant pathogenic bacteria has been a challenging issue because of several factors like lack of effective bactericides, the antibiotics being environmentally hazardous as well as noneconomic and phyto toxicity of the copper compounds rapid development of antibiotic resistant strains of bacteria, pathogen variability, high probability of mutation gene transfer, high mutation rates resulting in bacteria overcoming plant genetic resistance, (Jones et al., 2007; Balogh et al., 2010). The bacteriophage based biocontrol strategies are a potential alternative to antibiotics and can effectively solve the challenges of bacterial disease management. There are several advantages of the use of bacteriophages in bacterial disease management. Some of them are listed below (Jones et al., 2007; Buttimer et al., 2017; Wu et al., 2017):

\section{Bactericidal agents}

Once infected by an obligately lytic phage, bacteria will not regain their viability.

Table.1 Some major historical events about phage genome sequencing

\begin{tabular}{|c|c|c|c|c|c|}
\hline Sl. No. & Events & Phage Name & Nucleic Acid & Genome Size & Reference \\
\hline 1. & $1^{\text {st }}$ phage genome to be sequenced & $\varphi \mathrm{X} 174$ & ssDNA & $5,386 \mathrm{bp}$ & Sanger et al., 1977 \\
\hline 2. & $\begin{array}{l}\text { The first complete sequence of a } \\
\text { double-stranded DNA phage }\end{array}$ & Lambda & dsDNA & $48,502 b p$ & Sanger et al., 1982 \\
\hline 3. & Complete sequence of $\mathrm{T} 7$ phage & $\mathrm{T} 7$ & dsDNA & 39,936bp & Dunn et al., 1983 \\
\hline 4. & $\begin{array}{l}\text { The first complete sequence of a } \\
\text { double-stranded DNA phage } \\
\text { infecting a non-Escherichia coli }\end{array}$ & Mycobacterium Phage L5 & dsDNA & $52297 \mathrm{bp}$ & $\begin{array}{l}\text { Hatfull and Sarkis, } \\
1993\end{array}$ \\
\hline 5. & Phage T4 genome & $\mathrm{T} 4$ & dsDNA & $168,903 \mathrm{bp}$ & Miller et al., 2003 \\
\hline 6. & Smallest Podoviridae phage genome & Mycoplasma phage P1 & DsDNA & $11,660 \mathrm{bp}$ & Tu et al., 2001 \\
\hline 7. & Smallest Siphoviridae phage genome & Rhodococcus Phage RRH1 & dsDNA & $14,270 \mathrm{bp})$ & Petrovski et al., 2011 \\
\hline 8. & Smallest Myoviridae phage genome & Pasteurella phage F108 & dsDNA & $30,505-b p$ & Campoy et al., 2006 \\
\hline
\end{tabular}

Table. 2 Limitations of phage based biocontrol along with its possible remedies

\begin{tabular}{|l|l|l|}
\hline SI. No. & \multicolumn{1}{|c}{ Limitation of using phages based bio control } & \multicolumn{1}{c}{ Possible Remedies } \\
\hline 1. & $\begin{array}{l}\text { Narrow host range: Many phages are strain specific or } \\
\text { infects a few strains of the target bacterium }\end{array}$ & $\begin{array}{l}\text { A phage cocktail is required against a particular bacterial } \\
\text { disease to counter all the strains of the bacterial pathogen. }\end{array}$ \\
\hline 2. & $\begin{array}{l}\text { High production cost: Constant study and } \\
\text { improvisation of the phage based bio pesticide is } \\
\text { required from time to time. }\end{array}$ & $\begin{array}{l}\text { Once the protocols have been standardized, it does not take } \\
\text { much time and effort to carry out similar studies. Moreover, } \\
\text { molecular detection techniques can be used easily now days } \\
\text { with a reasonable price and a short time frame. }\end{array}$ \\
\hline 3. & $\begin{array}{l}\text { Temperate and transducing phages: The temperate } \\
\text { and transducing phages can convert susceptible bacteria } \\
\text { to a virulent one by horizontal gene transfer (HGT). }\end{array}$ & $\begin{array}{l}\text { Correct identification and selection required to eliminate the } \\
\text { temperate and transducing phages when using them for bio } \\
\text { control purposes. }\end{array}$ \\
\hline
\end{tabular}


Table.3 Phage based biocontrol experiments against some important plant pathogenic bacteria since the year 2010

\begin{tabular}{|c|c|c|c|c|}
\hline Pathogen & Disease & Host Plant & Information & Reference \\
\hline \multirow[t]{2}{*}{$\begin{array}{l}\text { Ralstonia } \\
\text { solanacearum }\end{array}$} & \multirow[t]{2}{*}{ Bacterial wilt } & Tomato & $\begin{array}{l}\text { Three lytic phages viz. } \Phi \text { RSA1, } \Phi \text { RSB } 1 \text { and } \Phi \text { RSL1 were used. Plants } \\
\text { treated with } \Phi \text { RSL1 gave complete control of the bacterial wilt disease } \\
\text { whereas the untreated plants showed wilting } 18 \text { days post infection. }\end{array}$ & $\begin{array}{l}\text { Fujiwara et al., } \\
\text { (2011) }\end{array}$ \\
\hline & & Potato & $\begin{array}{l}\text { Twelve lytic bacteriophages specific to } R \text {. solanacearum were isolated } \\
\text { and characterized. More than } 80 \% \text { of the potato plants could be } \\
\text { protected using phage cocktail and the same cocktail could kill } 98 \% \text { of } \\
\text { the live bacteria spiked in the sterilized soil one week after application. }\end{array}$ & Wei et al., (2017) \\
\hline \multirow[t]{2}{*}{ Dickeya solani } & \multirow[t]{2}{*}{ Soft Rot } & \multirow[t]{2}{*}{ Potato } & $\begin{array}{l}\text { The bio assays and field trials of two closely related and specific } \\
\text { bacteriophages, vB_DsoM_LIMEstone1 and vB_DsoM_LIMEstone2 } \\
\text { revealed that the phages reduced soft rot of inoculated tubers and also } \\
\text { produced a potato crop with higher yields. }\end{array}$ & $\begin{array}{l}\text { Adriaenssens et al., } \\
\text { (2012) }\end{array}$ \\
\hline & & & $\begin{array}{l}\text { A total of nine bacteriophages specific to Dickeya solani were isolated } \\
\text { from soil in Poland. Bioassays with the phages } \Phi \mathrm{D} 1, \Phi \mathrm{D} 2, \Phi \mathrm{D} 3, \Phi \mathrm{D} 4, \\
\Phi \mathrm{D} 5, \Phi \mathrm{D} 7, \Phi \mathrm{D}, \Phi \mathrm{D} 10, \Phi \mathrm{D} 11 \text { reduced the disease incidence of soft } \\
\text { rot by up to } 30-70 \% \text { on co-inoculated potato slices with pathogen and } \\
\text { phage. }\end{array}$ & $\begin{array}{l}\text { Czajkowski et al., } \\
(2014)\end{array}$ \\
\hline $\begin{array}{l}\text { Pseudomonas } \\
\text { tolassi }\end{array}$ & $\begin{array}{l}\text { Brown blotch } \\
\text { of mushroom }\end{array}$ & Mushroom & $\begin{array}{l}\text { The surfaces of mushroom caps were inoculated with both pathogenic } \\
\text { bacteria and their phages. Formation of blotches was completely } \\
\text { blocked by co-incubated phages. }\end{array}$ & Kim et al., (2011) \\
\hline $\begin{array}{l}\text { Xylella } \\
\text { fastidiosa } \\
\text { subsp. } \\
\text { fastidiosa (Xf) } \\
\end{array}$ & $\begin{array}{l}\text { Pierce } \\
\text { disease }\end{array}$ & Grapevines & $\begin{array}{l}\text { A phage cocktail was prepared for four } X \text {. fastidiosa specific phages } \\
\text { namely Sano, Salvo, Prado and Paz. Pierce disease symptoms could be } \\
\text { stopped using phage treatment with a cocktail of four phages post } \\
\text { infection as well as applying phage prophylactically to the grapevines. }\end{array}$ & Das et al., (2015) \\
\hline $\begin{array}{l}\text { Pectobacterium } \\
\text { carotovorum } \\
\text { subsp. } \\
\text { carotovorum }\end{array}$ & Soft rot & Lettuce & $\begin{array}{l}\text { The phage PP1 psecific to Pectobacterium carotovorum subsp. } \\
\text { carotovorum was isolated from soil which showed significant reduction } \\
\text { in disease development under green house trials. }\end{array}$ & Lim et al., (2013) \\
\hline
\end{tabular}




\section{Auto 'dosing'}

Phages are self- sustainable, self- replicating and self- limiting. They replicate as long as the host bacterium is present in the environment and degrade quickly in the absence of its host.

\section{Minimal disruption to micro biota}

Phages are target specific and do not harm the beneficial bacteria present in nature. Moreover, phages are prokaryotic viruses and hence, are completely harmless to the eukaryotes.

\section{Narrower potential for inducing resistance}

Phage resistance occurs in a small population size as they have a very narrow host range. Moreover, some phages use specific receptors (EPS, LPS, flagella, pilli etc.) in bacteria that are essential for survival in the infected hosts.

Mutations of the bacteria leading to resistance to the phages frequently results in loosing of virulence.

\section{Lack of cross-resistance with antibiotics}

The mechanisms used by the phages to infect bacteria completely differ from the mechanisms involved in antibiotic resistance.

\section{Rapid discovery}

Phages are abundant in nature and can be isolated from wherever the host bacterium is present like soil, water, plant surface, animals etc.

\section{Formulation and application versatility}

Phage based products are relatively easy and inexpensive to produce. Phages can be blended with creams, impregnated into solids, and applied as liquid preparations and hence, diverse formulations can be made.

\section{Prevent the formation of biofilms}

Due to their mode of action on the bacteria, bacteriophages are known to prevent the formation of these biofilms and hence can be used as a prophylactic measure to control the biofilm forming bacteria.

There are very few limitations of using phages as bio control agents which are listed in Table 2 along with their probable remedies:

Owing to its multiple advantages, numerous successful research works have been carried out in the present decade all over the world which itself is an evidence that bacteriophage have a great potential to be used as bio control agents. A selected summary of the phage based bio control experiments with respect to some important plant pathogenic bacteria since the year 2010 is shown in Table 3.

The true potential of the bacteriophages have only been understood in the present decade after more than a hundred years of its discovery. Bacteriophage therapy or phage based biocontrol is an exciting rediscovered field of bacterial disease management. Presently, although the use of phage based biocontrol is emerging, but is still an uncommon practice in the field of agriculture. Bacteriophages have several qualities which makes them potential biocontrol candidates. Moreover, the phage based biocontrol strategies will also help to overcome the challenge of antibiotic resistance up to a great extent. They are natural components and hence can be fitted in organic farming strategies. They can also be used as a component of the integrated management strategies as they can be combined with chemicals and other biocontrol agents. Scientific research for the development of 
phage based biocontrol strategies using modern biotechnological tools for isolating, characterizing, engineering, manufacturing and delivering phages will play a major role in shaping the future of phage based biocontrol practices.

\section{References}

Ackermann, H.W. (2005). Bacteriophage Classification. In: Bacteriophages: Biology and Application. Kutter E and Sulakvelidze A (Eds.). CRC Press. Boca Raton, London, New York, Washington, DC

Ackermann, H.W. (2009a). Basic phage electron microscopy. In: Bacteriophages: Methods and Protocols. Volume 1: Isolation, Characterization and Interactions. Clokie MRJ and Kropinski AM (Eds.). Humana Press, a part of Springer Science+ Business Media. New York, USA, pp. 113-126

Ackermann, H.W. (2009b). Phage classification and characterization. In: Bacteriophages: Methods and Protocols. Volume 1: Isolation, Characterization and Interactions. Clokie MRJ and Kropinski AM (Eds.). Humana Press, a part of Springer Science+ Business Media. New York, USA, pp. 127-140

Ackermann, H.W. and Prangishvili, D. (2012). Prokaryote viruses studied by electron microscopy. Arch Virol 157:1843-1849

Adams, M.H. (1959). Bacteriophages. Interscience Publishers, Inc., New York, pp.1-11

Adriaenssens, E.M., Van Vaerenbergh, J., Vandenheuvel, D., Dunon, V., Ceyssens, P.J., De Proft, M., Kropinski, A.M., Noben, J.P., Maes, M. and Lavigne, R. (2012). T4-related bacteriophage LIME stone isolates for the control of soft rot on potato caused by 'Dickeya solani'. PLoSONE 7: e33227

Bae, J. Y., Wu, J., Lee, H. J., Jo, E. J., Murugaiyan, S., Chung, E. and Lee, S.W. (2012). Biocontrol potential of a lytic bacteriophage PE204 against bacterial wilt of tomato. J. Microbiol. Biotechnol. 22, 1613-1620

Balogh, B., Jones, J. B., Iriarte, F. B. and Momol, M. T. (2010). Phage therapy for plant disease control. Curr. Pharm. Biotechnol. 11: 48- 57

Bradley, D.E. (1967). Ultrastructure of Bacteriophages and Bacteriocins. Bacteriological Reviews 31: 230-314

Brathwaite, K.J. (2015). Interactions between Campylobacters and their bacteriophages. Ph.D. thesis, University of Nottingham

Brenner, S. and Horne, R.W. (1959). A negative staining method for high resolution electron microscopy of viruses. Biochimica ET Biophysica Acta 34: 103-110

Buttimer, C., McAuliffe, O., Ross, R.P., Hill, C., O'Mahony, J. and Coffey, A. (2017). Bacteriophages and bacterial plant diseases. Front. Microbiol. 8:34

Campbell, A. (2006). General Aspects of Lysogeny. In: The Bacteriophages. Calendar, R. and Abedon, S.T. (Eds.). Oxford University Press, USA, pp. 6673

Campoy, S., Aranda, J., Alvarez, G., Barbe, J. and Llagostera, M. (2006). Isolation and sequencing of a temperate transducing phage for Pasteurella multocida. Appl. Environ. Microbiol. 72 (5): 3154- 3160

Ceyssens, P.J. (2009). Isolation and Characterization of Lytic Bacteriophages Infecting Pseudomonas aeruginosa. Ph.D. thesis, Katholieke Universiteit Leuven

Czajkowski, R., Ozymko, Z., and Lojkowska, E. (2014). Isolation and characterization 
of novel soil borne lytic bacteriophages infecting Dickeya spp. Biovar 3 " $D$. solani" Plant Pathol. 63, 758-772

Das, M., Bhowmick, T. S., Ahern, S. J., Young, R., and Gonzalez, C. F. (2015). Control of pierce's disease by phage. PLoS ONE. 10: e0128902

Donelli, G., Dore, E., Frontajx and Grandilfo, M. E. (1975). Structure and physiochemical properties of bacteriophage $\mathrm{G}$ III. A homogeneous DNA of molecular weight $5 \times 10^{8}$. J. Mol. Biol. 94: 555565

Doss, J., Culbertson, K., Hahn, D., Camacho, J. and Barekzi, N. (2017). A review of phage therapy against bacterial pathogens of aquatic and terrestrial organisms. Viruses. 9(3): 50

Dunn, J.J, Studier, F.W. Complete nucleotide sequence of bacteriophage T7 DNA and the locations of $\mathrm{T} 7$ genetic elements. (1983). J Mol Biol. 166:477-535

Fujiwara, A., Fujisawa, M., Hamasaki, R., Kawasaki T, Fujie $\mathrm{M}$ and Yamada $\mathrm{T}$ (2011). Biocontrol of Ralstonia solanacearum by treatment with lytic bacteriophages. Appl. Environ. Microbiol. 77, 4155-4162

Gill, J. and Hyman, P. (2010). Phage choice, isolation, and preparation for phage therapy. Curr. Pharm. Biotechnol. 11(1): $2-14$

Hatful, G.F. and Hendrix, R.W. (2011). Bacteriophage genomics. Curr Opin Virol. 1(4): 298-303

Hatfull, G.F. (2008). Bacteriophage genomics. Curr Opin Microbiol. 11(5): 447-453

Hatfull, G.F. and Sarkis, G.J. (1993). DNA sequence and gene expression of mycobacteriophage L5: a phage system for mycobacterial genetics. Mol. Microbiol. 7(3): 395-405

Jones, J.B., Jackson, L.E., Balogh, B., Obradovic, A., Iriarte, F.B. and Momol, M.T. (2007). Bacteriophages for Plant
Disease Control. Annu. Rev. Phytopathol 45: 245-62

Keen, E.C. (2015). A century of phage research: Bacteriophages and the shaping of modern biology. Bioessays. 37(1):6-9

Kim, M.H., Park, S.W., and Kim, Y.K. (2011). Bacteriophages of Pseudomonas tolaasii for the biological control of brown blotch disease. J. Appl. Biol. Chem. 54, 99-104

Klumpp, J., Dorscht, J., Lurz, R., Bielmann, R., Wieland, M., Zimmer, M., Calendar, R., Loessner, M.J. (2008). The terminally redundant, non-permuted genome of Listeria bacteriophage A511: a model for the SPO1-like myoviruses of gram-positive bacteria. $J$ Bacteriol.190, 5753-5765

Lim, J.A., Jee, S., Lee, D. H., Roh, E., Jung, K., Oh,C. and Heu, S. (2013). Biocontrol of Pectobacterium carotovorum subsp. carotovorum using bacteriophage PP1. J. Microbiol. Biotechnol. 23 (8): 1147-1153

Lwoff, A. (1953). Lysogeny. Bacteriology Reviews 17: 269-337

Miller, E.S., Kutter, E., Mosig, G., Arisaka, F., Kunisawa, T. and Ruger, W. Bacteriophage T4 genome. Microbiol. (2003). Mol. Biol. Rev. 67(1): 86-156

Orlova, E.V. (2012). Bacteriophages and their Structural Organization. In: Bacteriophages. Kurtboke, I. (Eds.). InTech, Jeneza Trdine 9, 51000 Rijeka, Croatia, pp. 3-30

Petrovski, S., Dyson, Z. A., Seviour, R. J. and Tillet, D. (2012). Small but sufficient: the Rhodococcus phage RRH1 has the smallest Siphoviridae genome at 14.2 kilobases. J. Virol. 86(1): 358-363

Rakhuba, D.V., Kolomiets, E.I.; Dey, E.S. and Novik, G.I. (2010). Bacteriophage Receptors, Mechanisms of Phage Adsorption and Penetration into Host 
Cell. Polish Journal of Microbiology 59: $145-155$

Sanger, F., Air, G.M., Barrell, B.G., Brown, N.L., Coulson, A.R., Fiddes, C.A., Hutchison, C.A., Slocombe, P.M., Smith, M. (1977). Nucleotide sequence of bacteriophage phi X174 DNA. Nature. 265:687-695

Sanger, F., Coulson, A.R., Hong, G.F., Hill, D.F., Petersen, G.B. (1982). Nucleotide sequence of bacteriophage lambda DNA. J. Mol. Biol.162:729-773

Summers, W.C. (2006). Phage and the Early Development of Molecular Biology. In: The Bacteriophages. Second Edition. Calendar R and Abedon ST (Eds.). Oxford University Press, New York
Tu, A.H.T., Voelker, L. L., Shen, X. and Dybvig, K. (2001). Complete nucleotide sequence of the mycoplasma virus P1 genome. Plasmid. 45: 122-126

Wei, C., Liu, J., Maina, A. N., Mwaura, F. B., Yu, J., Yan, C., Zhang, R. and Wei, H. (2017). Developing a bacteriophage cocktail for biocontrol of potato bacterial wilt. Virol. Sin. 32 (6): 476484

Wu, S.B.S., Zachary, E., Wells, K. and LocCarrillo, C. (2013). Phage Therapy: Future Inquiries. Postdoc J. 1(6): 24-35

Yuan, Y. and Gao, M. (2017). Jumbo bacteriophages: an overview. Front Microbiol. 8: 403

\section{How to cite this article:}

Barua, P. and Nath, P.D. 2018. Bacteriophages: A Potential Next Generation Biocontrol Tool for Plant Disease Management. Int.J.Curr.Microbiol.App.Sci. 7(09): 1103-1112. doi: https://doi.org/10.20546/ijcmas.2018.709.131 